NBER WORKING PAPER SERIES

THE ROLE OF PATENT PROTECTION IN (CLEAN/GREEN) TECHNOLOGY TRANSFER

\author{
Bronwyn H. Hall \\ Christian Helmers \\ Working Paper 16323 \\ http://www.nber.org/papers/w16323 \\ NATIONAL BUREAU OF ECONOMIC RESEARCH \\ 1050 Massachusetts Avenue \\ Cambridge, MA 02138 \\ September 2010
}

Parts of this survey are based on presentations by the first author to a WIPO Conference in Mexico City, January 2008 and a KDI Conference in Seoul, February 2010. We are grateful to participants at those conferences and to Estelle Derclaye and Fabio Montobbio for comments on an earlier draft. The views expressed herein are those of the authors and do not necessarily reflect the views of the National Bureau of Economic Research.

NBER working papers are circulated for discussion and comment purposes. They have not been peerreviewed or been subject to the review by the NBER Board of Directors that accompanies official NBER publications.

(C) 2010 by Bronwyn H. Hall and Christian Helmers. All rights reserved. Short sections of text, not to exceed two paragraphs, may be quoted without explicit permission provided that full credit, including (c) notice, is given to the source. 
The role of patent protection in (clean/green) technology transfer

Bronwyn H. Hall and Christian Helmers

NBER Working Paper No. 16323

September 2010

JEL No. O19,O33,O34,Q54,Q55,Q58

\begin{abstract}
$\underline{\text { ABSTRACT }}$
Global climate change mitigation will require the development and diffusion of a large number and variety of new technologies. How will patent protection affect this process? In this paper we first review the evidence on the role of patents for innovation and international technology transfer in general. The literature suggests that patent protection in a host country encourages technology transfer to that country but that its impact on innovation and development is much more ambiguous. We then discuss the implications of these findings and other technology-specific evidence for the diffusion of climate change-related technologies. We conclude that the "double externality" problem, that is the presence of both environmental and knowledge externalities, implies that patent protection may not be the optimal instrument for encouraging innovation in this area, especially given the range and variety of green technologies as well as the need for local adaptation of technologies.
\end{abstract}

Bronwyn H. Hall

Dept. of Economics

549 Evans Hall

UC Berkeley

Berkeley, CA 94720-3880

and NBER

bhhall@nber.org

Christian Helmers

Centre for Economic Performance

Houghton Street

London WC2A 2AE, United Kingdom

c.r.helmers@1se.ac.uk 


\section{Table of Contents}

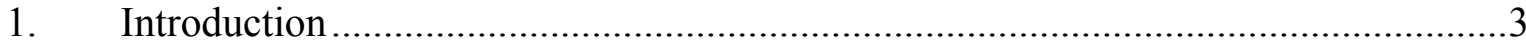

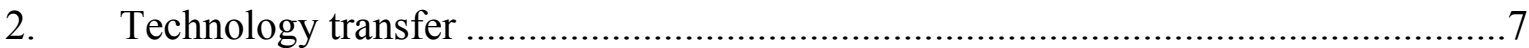

2.1 Technology transfer through trade...................................................... 8

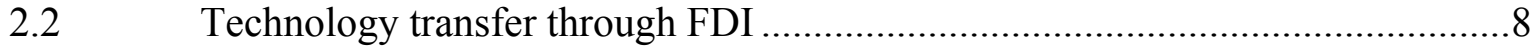

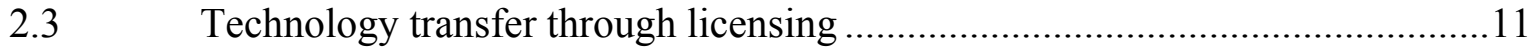

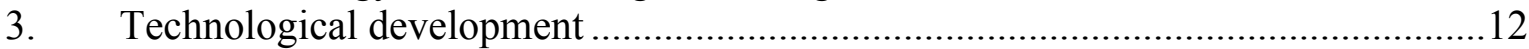

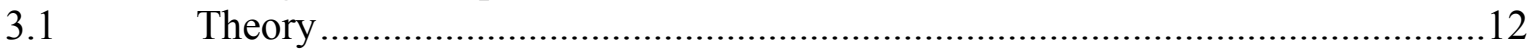

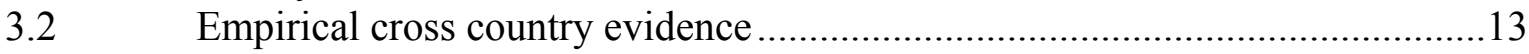

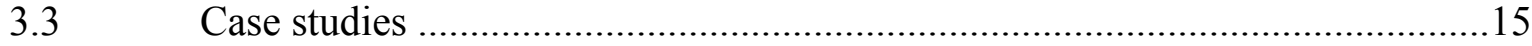

4. Implications for climate-related technologies ...................................................18

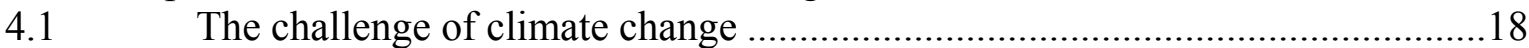

4.2 Climate change-related technologies .......................................................19

4.3 Climate change-related policy intervention ...........................................20

4.4 Climate change-related technology development....................................22

4.5 Climate change-related technology transfer ................................................24

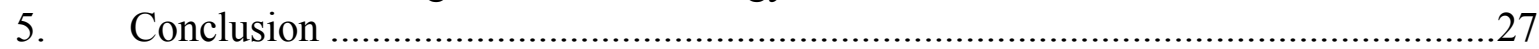

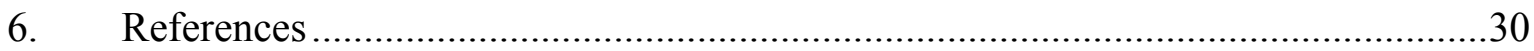




\title{
The role of patent protection in (clean) technology transfer
}

\author{
Bronwyn H. Hall ${ }^{2}$ \\ Christian Helmers ${ }^{3}$ \\ August 2010
}

\section{Introduction}

The worldwide challenge of climate change mitigation has led to an increased interest in the mechanisms that encourage the development and adoption of new technologies. In particular, recent rapid economic growth in several large developing economies has focused policy attention on the role of technology transfer and technology development in countries that are not generally on the technology frontier in facilitating the use of clean technologies. In addition to the obvious fact that raising the standard of living in such countries to levels enjoyed in the West without a great deal of energy and environmentrelated innovation would have detrimental consequences for global warming, it is also true that rapid growth means a great deal of new investment, and new investment is an opportunity for substantial upgrading of technologies. At the same time, according to existing forecasts, the countries contributing most to climate change are not those that will be affected most heavily by the consequences. The geographical disparity, placing developing countries at a disadvantage, poses additional incentive problems to the development and transfer of green technologies and the setting of research priorities.

The emission of greenhouse gases leads to a range of well-documented consequences, such as increases in the average global temperature, greater variation in temperatures across time, increased frequency and intensity of extreme weather-related events, and average sea-level rise (IPCC, 2007). The potential damages induced by climate change are manifold, in particular for developing countries where climate change is expected to have its most severe repercussions. Developing countries depend to a large extent on the agricultural sector, which is particularly vulnerable to climatic changes (World Bank, 2010). Climate change may also have a negative impact on public health in developing countries by for example increasing malaria morbidity and mortality (Tol, 2008; WHO, 2009). Another important consequence is the increased risk of natural disasters, mostly in coastal areas of developing countries. Contemplating these risks, climate change may also increase the likelihood of displacement, political unrest and violent conflict in developing countries. Developing countries, therefore, have a strong interest in containing climate change and mitigating its consequences through the development and diffusion of green technologies.

\footnotetext{
${ }^{2}$ University of California at Berkeley and University of Maastricht. bhhall@econ.berkeley.edu

${ }^{3}$ CEP LSE and CSAE University of Oxford. c.r.helmers@1se.ac.uk
} 
The development and diffusion of technology in the context of climate change poses a formidable challenge due to the presence of a "double externality":

First, environmental pollution is a textbook example of an activity producing a negative externality, i.e., "an unintended consequence of market decisions which affect individuals other than the decision maker" as the social costs associated with pollution exceed private costs (Stavins, 2008,1). Second, knowledge required for the development of (green) technologies is characterized by non-excludability, i.e., other actors cannot be excluded from accessing and using the knowledge produced by the original source and non-rivalry or non-exhaustibility of knowledge, i.e., if one actor uses some specific knowledge, the value of its use is not reduced by other actors' also using it. Due to these characteristics, "firms can acquire information created by others without paying for that information in a market transaction, and the creators (or current owners) of the information have no effective recourse, under prevailing laws, if other firms utilize information so acquired" (Grossman and Helpman, 1991,16). In this sense, incomplete appropriability of knowledge represents an externality and thus leads to a gap between private and social returns to innovation. ${ }^{4}$ Addressing these externalities individually is challenging; in reality, however, the two externalities also interact, which further compounds the problem (Jaffe et al., 2005). For example, there is enormous uncertainty linked to both climate change and to the development and effectiveness of new technologies. The interaction of uncertainties associated with climate change and innovation complicates the design of appropriate policy interventions to mitigate the impact of and also adapt to climate change (Heal and Kriström, 2002). What is more, both externalities act on a global scale, which poses a particularly difficult problem in their mitigation.

The presence of the dual externality problem implies that at least two different policy instruments are needed. For example, addressing environmental externalities and knowledge spillovers simultaneously through targeted R\&D subsidies is likely to fail, largely because two sets of actors are involved; the producers of technology will respond to the subsidy, but adoption of green technologies resulting from subsidized research will not occur at an optimal scale in the absence of a policy intervention directly targeting diffusion (we discuss this "energy efficiency paradox" further below). Because of the presence of sunk switching costs, for potential users to be persuaded to replace existing technologies with green ones requires either a clear price signal that energy costs are high, (and will stay high), or subsidies that can overcome the sunk costs. ${ }^{5}$ Acemoglu et al. (2009) make the same argument in an endogenous growth model that allows for technological change directed either towards carbon-emitting or green technologies. In a setting in which polluting technologies are initially more productive, the authors show that research subsidies are needed to redirect innovation towards climate change-related

\footnotetext{
${ }^{4}$ For a recent discussion of this point see Chapter 1.5 in Greenhalgh and Rogers (2010).

${ }^{5}$ While subsidies can lead to diffusion, they may fail to lead to actual use of a new technology. For example, in the case of improved cooking stoves (ICS) that rely on biomass in developing countries, subsidies have been used to help overcome the large up-front investment involved in the replacement of a traditional stove by an ICS. Barnes et al. (2003) suggest that while subsidies have promoted diffusion, they did not guarantee the actual use of ICS which depended mostly on how suitable the design of the stove was to specific local needs. For example, traditional stoves also fulfilled functions other than cooking, such as heating and protection from insects, whereas the design of ICS did not provide these additional benefits (Agarwal, 1983).
} 
technologies. However, a tax penalizing carbon emissions is also needed to address the environmental externality. Their analysis suggests that policy intervention in the form of subsidies and taxes is needed only temporarily, although delaying the intervention is costly.

IP has been widely studied as a means to addressing the externality that results from imperfect appropriability of knowledge. The trade-off between a static efficiency loss due to higher prices in the presence of patents and potential dynamic gains from providing incentives for investment in innovation is well-known (Nordhaus, 1969). However, given the presence of the environmental externality, potential interactions between the environmental and knowledge externalities, the global dimension of the problem and the vast range of different green technologies applicable to the problem, the question of the role of IP protection in promoting the development and transfer of technology needs to be re-examined. In particular, when compared to other forms of stimulating innovation such as subsidies or tax credits, the IP instrument has the well-known welfare cost that it tends to grant firms short term market power, which leads to lower output and higher prices for innovation. In the presence of the second (negative) environmental externality, this welfare cost is likely to be greater because social welfare is enhanced by the rapid diffusion of green technology. Therefore, patents may not be the preferred policy instrument for encouraging innovation in this area if they fail to create a competitive market for technology that leads to more diffusion than would be achieved in their absence.

The question of the role of IP is important in light of the ongoing discussion on how to address climate change. In its latest report, the UN Framework Convention on Climate Change (UNFCCC) Ad-hoc Working Group on Longterm Cooperative Action (AWGLCA) proposed specific IP-related regulations for the post-Kyoto framework on climate change. The regulations proposed by developing countries include patent pooling, royaltyfree compulsory licensing of green technologies, excluding green technologies from patenting, and even revoking existing patent rights on green technologies (UNFCCC, 2010). In fact, these exceptions to standard patent regulations are already partially contained in the Agreement on Trade Related Aspects of Intellectual Property Rights (TRIPS) which allows for exceptions to the exclusive rights of patents for public policy reasons and provides for the possibility of compulsory licensing (Derclaye, 2008; Rimmer, 2009). ${ }^{6}$ The Doha Declaration on TRIPS and Public Health goes a step further in the area of pharmaceutical patents. Considering the public good character of environmental protection in the recent debate on climate change-related technology transfer from developed to developing countries, a parallel has been drawn between implications for developing countries from patent protection in the pharmaceutical sector and green technologies (Abbott, 2009).

In contrast, industrial economies such as the U.S. are committed to 'prevent any weakening of, and ensure robust compliance with and enforcement of, existing international legal requirements . . . for the protection of IP rights related to energy or environmental technology (U.S. House of Representatives as quoted in Rimmer, 2009).

\footnotetext{
${ }^{6}$ Articles 7, 8, 27.2, 31 TRIPS. Note that despite the possibility of compulsory licensing, its benefits are limited inasmuch as the licensor cannot be obliged to transfer the corresponding know-how to the licensee (Derclaye, 2008).
} 
Derclaye (2009) argues that the patent system should even be used to promote green technologies and eliminate technologies that lead to increased $\mathrm{CO}_{2}$ emissions. In accordance with this view, the USPTO launched in December 2009 its 12-month "Green Technology Pilot Program," under which patents related to green technologies benefit from a substantially accelerated examination process. The UKIPO launched a similar initiative in May 2009. The underlying assumption is that speedier grants of patents will spur the development and diffusion of green technologies. ${ }^{7}$ But is the existing evidence consistent with this view?

If we unpack the question about the relationship between the strength of the patent system and innovation in developing countries in a general context, we find that there are at least two separate but related questions whose answers may be at odds with each other. The first is whether stronger patent protection in a host country encourages technology transfer to that country. In particular, how does the presence of patent protection affect the behavior of foreign firms that may potentially invest in the country, sell technology to firms in the country, or form joint ventures with domestic firms? The second question is whether stronger patent protection encourages technology development in the country itself. That is, how does it affect the behavior of domestic firms? The first question has been easier to answer, but the second is more important for the development of the country in question. The second question may be particularly important in the context of climate change, as required technologies may not be the same in developed and developing countries. In this case, industrialized economies may not have the incentives to engage in the development of technologies exclusively or predominantly required by developing countries. This forces developing countries to provide incentives to either adapt existing technologies to their specific needs or to develop these technologies domestically.

With respect to the first question, a priori it seems clear that stronger IP protection in the host country should encourage (or at least not discourage) the (active) transfer of technology in embodied form through imports of capital goods, by foreign firms to their subsidiaries and possibly to domestic firms, either via direct investment in the form of partnership or licensing. Note that this argument presumes that the intellectual property rights (IPRs) are enforceable, which is not an innocuous assumption. Also, note that such transfer may or may not help the local development of innovation skills and human capital in particular when only embodied knowledge is transferred. With respect to the second, it also seems clear that stronger IP protection could encourage the innovative activities of domestic firms, but could also discourage learning via imitation and therefore inhibit technological catch-up. Which effect dominates also depends on the level of technological development already attained in the host country as technology transfer requires absorptive capacity in the recipient country.

The available evidence, which we summarize later in the paper, suggests that, "one-sizefits-all" harmonization of intellectual property rights is not welfare-enhancing for less developed countries (and possibly not even for emerging economies), although for large

\footnotetext{
${ }^{7}$ Note that the definition of eligible patents under these fast-track schemes appears to be somewhat arbitrary given the difficulty of defining objective technology-based criteria (for the USPTO classification see the Federal Register Vol. 74, No. 234). This is particularly evident in the case of the UKIPO 'green channel', where applicants are only required to explain themselves in writing why the technology for which patent protection is sought is green (see http://www.ipo.gov.uk/p-pn-green.htm).
} 
emerging economies there is also little evidence that it would lead to a welfare loss. With respect to climate change-related technologies, as suggested by the World Bank 2010 World Development Report, "[ $\mathrm{t}$ ]here is no evidence that overly restrictive IPRs have been a big barrier to transferring renewable energy production capacity to middle-income countries. . . . In low-income countries, weak IPRs do not appear to be a barrier to deploying sophisticated climate-smart technologies." (World Bank, 2010,310). Moreover, the available evidence suggests that the parallels in terms of IP protection drawn between the pharmaceutical industry and green technology are not warranted. A large range of different technologies can achieve emission reductions, and for a significant share of these green technologies, the underlying technology is mature and in the public domain. Most technological progress is expected to come from incremental improvements of existing offpatent technologies. While such incremental innovation may be patentable, it leaves ample scope for competing technologies and therefore limits the role specific patents may play for technological progress in this area (Johnson and Lybecker, 2009a). ${ }^{8}$ This suggests that insights from the existing experience with technology development and transfer in certain technological areas such as pharmaceuticals may not translate directly to green technologies.

This paper specifically addresses the implications of the IP-technology transfer relationship for climate change mitigation in developing countries. However, we note that there are already a number of useful surveys of the general topic available in the literature. ${ }^{9}$

\section{Technology transfer}

International technology transfer typically takes place via trade, foreign direct investment, joint ventures with local partners, or simple technology licensing, although in the latter case, some tacit knowledge probably also needs to be transferred. ${ }^{10}$ In all of these cases, foreign firms run the risk that imitation by local firms may erode some of their profits from these activities, so the presence of enforceable IPRs should encourage these activities. ${ }^{11}$ In

\footnotetext{
${ }^{8}$ Supporting this line of argument, Arora and Gambardella (2010) provide evidence from the chemical industry in which quick and extensive diffusion of new technologies occurred in the presence of effective patent protection. Arora and Gambardella argue that diffusion was possible despite strong patent rights because firms were able to develop variants of patented chemical processes which led to effective competition in the market for technology.

${ }^{9}$ For earlier surveys on technology transfer and IP see Branstetter (2004), Maskus (2004), ICTSD, and UNCTAD (2003); for surveys on innovation and climate change see Popp et al. (2010), Popp (2010), and World Bank (2010, Chapter 7).

${ }^{10}$ See Keller $(2004,2010)$ for overviews of the literature on international technology diffusion.

${ }^{11}$ Wright and Pardey (2006) note that there is often confusion regarding the scope of patent protection. A patent is only valid in the country in which it is registered, which means that firms in countries where a technology is not protected can use the technology without infringing the patent. At the example of patents on transgenic traits, Wright and Pardey argue that despite strong IPR protection in the US where most cultivars with transgenic traits have been developed, technology diffusion to developing countries was not hampered. Wright and Pardey (2006) argue that it is rather the lack of public investment in agricultural research that accounts for the lack of innovation in developing countries in this area than IPR protection. The authors suggest that adaptation of new traits might even be faster in developing countries if stronger IPR protection were in place.
} 
fact, Edith Penrose goes as far as to argue that for developing countries, "the only economic advantages to be gained from granting foreign patents lies in the possibility that in one way or another such grants will induce the introduction of foreign technology and capital." (Penrose, 1973,770). Obviously, in the cases of more advanced technology, the imitation risk is highest when the host country has the capacity to adopt and develop such technology, which implies that the risk is generally greater in middle income countries than in low income countries. This risk is further increased if technologies require local adaptation in order to fit local needs and regulatory requirements and standards. At the same time, if IPR protection is strong, foreign firms may prefer to license technologies instead of choosing to be a local presence, which could decrease the amount of (tacit) knowledge transferred. This decision may also be influenced by the ability of foreign firms to enforce license contracts. However, it is also conceivable that stronger IPRs increase the incentives for firms to exploit IPRs themselves instead of licensing out. It is likely that these relationships differ by industry and type of activity, i.e., manufacturing or distribution.

How true is this in practice? That is, what is the evidence that local IP protections matter when a firm considers transferring its technology to another country?

\subsection{Technology Transfer Through Trade}

Maskus and Penubarti (1995) provide some empirical evidence for a positive correlation between the strength of patent enforcement and the level of manufacturing imports originating in Organisation for Economic Co-Operation and Development (OECD) countries using a cross-section of twenty-eight manufacturing sectors across forty-seven developed and developing countries. The authors found that the level of manufacturing imports is positively correlated with the strength of patent enforcement in the importing countries. The authors also account for the potential endogeneity of the patent enforcement measure by using an instrumental variable approach (although finding valid instruments in this context is a difficult task). In a similar analysis, Smith (1999) looks at the correlation between U.S. exports and IPR protection in developing countries by estimating a gravity equation. Smith distinguishes among countries with differing degrees of threatened imitation -that is, the importing country's ability to imitate. She finds a positive correlation between U.S. exports and the importing country's strength of IP protection only for countries with high risk of imitation. These findings have been confirmed more recently by Awokuse and Yin (2010) who look specifically at the relationship between imports and IPR protection in China using panel data for 1991-2004. In addition to a patent right index, Awokuse and Yin use patent applications by foreign applicants as a measure for the strength of IPRs in China. Awokuse and Yin find that imports by China increase with stronger patent rights protection and that this effect is strongest for high-tech industries.

These results suggest that trade serves as a channel for international technology transfer, and that developed countries are wary of transferring knowledge in embodied form to countries with strong imitative capacity and weak IPR enforcement.

\subsection{Technology Transfer Through FDI}

The first author to empirically look at Foreign Direct Investment (FDI) as a channel for technology transfer was Edwin Mansfield in a 1991 survey of approximately 100 U.S. 
multinational firms (Mansfield, 1994) and their experiences with sixteen countries from all over the world. Broadly speaking, his findings were that most U.S. multinationals evaluate the strength of IP protections in the host country before making investments abroad; the effects varied by industrial structure and, not surprisingly, were especially strong in the case of R\&D facilities and in the chemical and or pharmaceutical sector. In assessing the evidence, Mansfield was careful to point out the three factors that led to the firm's perception of IP strength: (1) does the law protect their technology?; (2) is there adequate legal infrastructure in the country to enable enforcement?; and (3) do the relevant government agencies treat foreign entities the same as domestic entities in this area? All three were to be taken into account in answering the survey.

In Lee and Mansfield (1996), these data are augmented with data on actual foreign direct investment by U.S. firms in the countries during four years from 1990 to 1993, and simple regressions are used to show that FDI does indeed vary with the perceived strength of IP protection. Mansfield (2000) performs a similar exercise using data on firms in Japan and Germany as well as the U.S. and finds even larger effects. Given the relatively small sample size in the U.S. study (effectively sixteen countries, although there are forty-eight observations due to the time dimension), this result is reassuring.

Heald (2003) critiques the strength of the conclusions drawn from this study as making too little a distinction among the different kinds of IP rights that might be used. In particular, although the study is often cited to show that patents are important for technology transfer, Heald argues that trade secrecy may have been equally important in the eyes of the survey participants. The original Mansfield article cites a number of comments by survey participants that suggest disclosure of proprietary information is what they fear most. As Heald points out, this information is already disclosed if the invention has been patented elsewhere, so the presence or absence of local patent protection may be irrelevant. Turner and Heald (2004) propose a new survey that distinguishes among the various kinds of IP rights, but unfortunately, their survey achieved response rates that were too low for valid analysis (Turner, 2010, private communication with author).

In a major study of U.S. multinational firm behavior in response to the strengthening of patent systems in sixteen middle income countries during the 1990s, Branstetter et al. (2006) found that royalty payments received for technology, R\&D spending by the firm's local affiliates, and foreign-origin patent applications at the USPTO all increased following these changes, especially if the firm in question was already a heavy patent user and therefore presumably dependent on patents to secure returns to innovation.

Javorcik (2002) studies the relationship between a country's probability of receiving FDI and its level of IP protection for twenty-four Eastern bloc transition economies for the period 1989-1994. Javorcik uses the Ginarte and Park (1997) IPR index which measures statutory IP enforcement and complements it with information on actual IPR enforcement. Her findings suggest that the level of IPR protection is positively correlated with the propensity to receive FDI in high-tech sectors. ${ }^{12}$ In countries with weak IPR protection, FDI focuses on distribution activities instead of the establishment of local production facilities. In a similar analysis, Park and Lippoldt (2008) analyze the relationship between

\footnotetext{
12 "High-tech sectors" were defined as including: (1) drugs, cosmetics, and health care products; (2) chemicals; (3) machinery and equipment; and (4) electrical equipment.
} 
the strength of IPRs and technology transfer measured as inward FDI stocks and imports of goods and services for a sample of 120 countries over the period 1990-2005. The authors construct separate Ginarte-Park type indices for patents, trademarks, and copyrights to measure the strength of IP protection in a given country. The authors find the patent rights index is positively correlated with all three measures of technology transfer. This positive relationship is weaker for trademarks and copyrights. With regard to technology transfer to developing countries, Park and Lippoldt find a positive association between stronger patent rights and high-tech imports such as pharmaceuticals, chemicals, and office and telecom equipment. Their data also suggests a positive correlation between the number of patents held by non-residents in developing countries and the amount of FDI and imports of goods and services received. The authors argue that this shows that foreigners transfer new technologies in the presence of strong IP rights.

The literature reviewed above treats FDI as a single homogenous channel of technology transfer. Ito and Wakasugi (2007) distinguish between different types of FDI. They estimate the probability of affiliates of Japanese manufacturing multinational companies engaging in $R \& D$ in a sample of developed and developing host countries where they distinguish between affiliates conducting $\mathrm{R} \& \mathrm{D}$ at the plant site without the establishment of a research laboratory, and at both the plant site and a research laboratory. Ito and Wakasugi interpret the former as a sign that an affiliate conducts only R\&D to adapt existing technologies to the host market, whereas the latter is regarded as "knowledge sourcing R\&D" which involves the creation of new knowledge and technologies. Ito and Wakasugi find a positive correlation between the strength of a host country's IPR enforcement regime measured as a patent right index and the probability of a Japanese affiliate conducting knowledge sourcing R\&D. Since this type of R\&D can be expected to have the largest technology transfer component, the finding also suggests that stronger IPRs are correlated with increased technology transfer through the channel of FDI.

While this literature suggests that IPR enforcement is important, there may be a large number of other factors that also influence multinational companies' decisions to engage in FDI. Fosfuri (2004), for example, compares the importance of IPR protection and country risk in determining international investment activities of large multinational chemical processing firms in seventy-five countries during the period 1981-1996. Fosfuri has information on three modes of international activity of the firms in the sample, i.e., whollyowned operations, joint ventures, and licensing. He finds firms to be sensitive to the measure of country risk, measured by the Institutional Investor Credit ratings, with all three forms of a foreign firm's engagement being negatively correlated with country risk in the host economy. In contrast, the level of IPR protection is not correlated in a statistically significant way with any form of foreign firms' engagement in the host economy. This may be partly explained by the fact that the measure of IPR protection is based on statutory protection and might differ from actual enforcement. ${ }^{13}$ It suggests that IPRs are only part of a more complex set of FDI determinants.

Does this also help explain why we often see foreign R\&D investments in countries with weak IPR enforcement? Zhao (2006) looks into this seeming conundrum, analyzing data on 1,567 holding companies headquartered in the U.S. and active in forty-eight developing

\footnotetext{
${ }^{13}$ Fosfuri (2004) also uses the index proposed by Ginarte and Park (1997) - see also Section 3.
} 
and developed countries. Zhao shows that patents filed at the USPTO by these companies receive more forward citations within a holding company if at least half of the inventors of the patent are located in a country with weak IPR protection. Zhao interprets this selfcitation pattern within a holding company as evidence for disproportionately more knowledge exchange internal to the holding company in the case of research undertaken in countries with weak patent protection. Hence, the results suggest that multinational companies conduct R\&D in countries with weak IPR protection when the resulting innovation is integrated into larger global $\mathrm{R} \& \mathrm{D}$ projects of the holding company. In this case, the value of an innovation emerges only when it is integrated and complemented with knowledge and resources held by the company abroad. Therefore, the potential loss due to imperfect appropriability of knowledge in these countries is counterbalanced by inexpensive researchers in developing countries, and this explains a company's' willingness to engage in FDI in developing countries with weak IPR protection. Chen (2008) suggests that the availability of a large pool of highly-skilled, specialized scientists is even more important than low wages. He investigates the motives of multinational companies to establish R\&D labs in Beijing. The results of his qualitative survey of eighteen $R \& D$ labs established by multinational companies in Beijing also reveals a range of other relevant location-specific factors such as the possibility to conduct joint research projects with local research institutions and competitive pressures on local markets to generate innovative products.

In summary, the literature indicates a positive correlation between FDI and the level of IPR enforcement. Considering the extensive evidence on FDI serving as a channel for technology transfer, this implies a positive relation between IPR enforcement and technology transfer through the channel of FDI. However, the literature also points to other important factors in attracting FDI, such as country risk and the availability of low-cost highly-skilled labor.

\subsection{Technology Transfer Through Licensing}

Arora and Ceccagnoli (2006) use data from the 1994 Carnegie Mellon Survey on U.S. manufacturing firms conducting $R \& D$ to investigate the relationship between firm licensing behavior and the strength of patent protection. The authors find that the effect of stronger patent protection on licensing depends on whether the firm owns specialized complementary assets. If they do not, stronger patent protection increases their propensity to license their technology. If they have such assets, stronger patent protection leads them to patent more but not necessarily to license more. Hence, the positive association between the strength of patent protection and licensing found by the authors comes from firms' increased patenting activity rather than a direct increase in firms' licensing activities.

Smith (2001) uses a sample of U.S. firms to analyze how the strength of patent regimes abroad influence the way in which these firms service foreign markets. She finds a stronger positive association between licenses by U.S. firms in countries with stronger IPR enforcement than for exports and sales by affiliates. Smith interprets her findings as evidence that strong IPRs give incentives to U.S. firms to transfer knowledge to foreign companies through licensing. Yang and Maskus (2009) support Smith's findings in a theoretical model. Yang and Maskus show that stronger IPRs give incentives to firms from industrialized countries to license technology to firms in developing countries. If these 
developing country firms have sufficient absorptive capacity, licensing may lead them to increase exports and therefore enhance welfare in the developing country.

In summary, the main conclusions from the empirical evidence on IP and technology transfer are the following: first, the strength of IP protection does seem to facilitate technology transfer to middle income countries that already have innovative capacity or are capable of imitation. Technology licensing, imports, and foreign direct investment in these countries respond to stronger IP regimes. The existing evidence also suggests that absorptive capacity is important. It facilitates technology transfer through licensing, which is the channel involving the most disembodied technology transfer external to the multinational company. These conclusions appear consistent with the idea that a certain level of absorptive capacity is necessary to make use of and learn from imported technology, but if a country has the capacity to do so, they are more likely to receive the technology if the foreign firm from which it comes feels that its ownership rights will be protected. If the absorptive capacity is present but IP protection is weak, foreign firms will tend to establish distribution rather than manufacturing subsidiaries. Despite evidence that IP protection sometimes encourages technology transfer, it is important to remember that firms typically do not rank IPRs highly as an influence on the technology transfer decision, except in the cases of R\&D facilities and very advanced technologies. Thus, specific situations will require specific evaluations.

\section{Technological Development}

The results on IP and technology transfer seem sensible and consistent with a priori intuition. However, as suggested in the introduction, the more important question for policy is the degree to which strong IPRs impact innovation and development within a developing country. Does stronger patent protection help to enable and increase that country's own innovative capacity? Economists have approached this question in three different ways: (1) using theoretical analysis; (2) looking at the empirical relationship between IP and innovation across countries; and (3) using individual case studies of changes in patent law.

\subsection{Theory}

Chin and Grossman (2000) use a highly stylized model to assess welfare effects on developing countries adopting patent protection for innovations from developed economies in the presence of North-South trade. Under a number of restrictive assumptions, Chin and Grossman find for their two-country model that the Southern country's welfare is lower when granting patent protection to innovations from the North. In contrast, the North always gains from patent protection in the South. Deardorff (1992) reaches a similar conclusion for his static two-country model, suggesting that global welfare may even decrease if patent protection is extended to the South. Grossman and Lai (2004) look at the choice of levels of IP protection among groups of countries that are subject to knowledge spillovers. They find that, in general, non-cooperative equilibria among these countries result in stronger IP protection in developed countries than in the less developed countries. Angeles (2005) uses a simple North-South model with IPRs in the North and finds that the welfare effects of adding IP protection in the South depends on the relative income levels 
in the North and South; the larger the gap, the less desirable IP protection in the South is for total social welfare.

Scotchmer (2004) considers a case where each country can choose to have innovation provided either by IP protection for innovators or by public sponsorship of innovation. In this case, national treatment of innovators and harmonization across countries both lead to too much IP protection and too little public sponsorship in all of the countries relative to the social welfare optimum. Small countries will favor more extensive harmonization of IP rights than large countries if everything else is equal, because the consumer surplus they generate is in other countries for the most part. In addition, more innovative countries will favor more extensive IP rights.

\subsection{Empirical Cross Country Evidence}

Few well-designed natural experiments exist for the study of IP protection and innovative activity, and most are not specifically addressed to the development question. There are, however, a fairly large number of simple cross country studies, both contemporary and historical. These studies vary in quality due to the presence of simultaneity between the development of an economy and the development of an IP system, although some of the authors have attempted to find instrumental variables to mitigate this problem.

There are two large scale historical studies, both of which take advantage of the variability of patent systems around the world in the $19^{\text {th }}$ century. Lerner (2002) compares patenting activity in the UK across countries with various strengths of the patent system and finds that patenting by domestic entities at the UK patent office actually declines when their patent system is strengthened, whereas patenting by foreign entities increases. Moser (2005) uses Crystal Palace exhibits as a proxy measure of innovative activity and finds that countries with stronger patent systems do not produce more innovation, but that innovation in countries with weak or no patent systems tends to favor technologies that can be protected by trade secrets. Thus, both of these investigations fail to find strong overall effects of patenting on innovation in the $19^{\text {th }}$ century.

In the first study of this kind using contemporary data, Park and Ginarte (1997) use aggregate data for sixty countries during 1960-1990 and an index of the strength of IP rights (subject matter coverage, term length, etc.). Using a simultaneous equations model of economic growth, investment, schooling, and R\&D investment, they found that the strength of IP rights was positively associated with investment and R\&D investment in countries with above-median income, but not for less-developed countries. IP rights had no independent effect on growth above and beyond that contributed by investment and R\&D. However, Ginarte and Park (1997) also show that the strength of IP rights in high income countries (but not in low income countries) can be predicted by prior R\&D intensity, which raises some questions about the simultaneity of IP protection and a country's orientation towards R\&D and innovation. That is, it is possible that the demand for IP protection increases when a large share of the industrial base is engaged in innovative activities. In a more recent study, Allred and Park (2007) use an updated patent rights index to look at the relation between IPR protection and patenting at the country level for a sample of 100 countries during 1965-2000. Allred and Park find a non-linear relationship between the IPR index and domestic patenting - for low values of the index, a strengthening of IPR enforcement is negatively correlated with patent counts whereas the relationship is positive 
beyond a threshold level of the index. Also using the Ginarte-Park patent rights index, Park and Lippoldt (2008) find for their analysis a positive correlation between patent strength and the number of patent applications by developing countries as well as R\&D intensity, i.e., R\&D expenditure as a percentage of GDP. The authors interpret this as evidence for stronger IP rights to be beneficial for the domestic development of technology in developing countries.

The study by Kanwar and Evenson (2003) looks at the variation across countries in R\&D spending as a function of the Ginarte-Park index over the 1981-1990 period for a sample of thirty-two countries and finds similar results, with stronger IP protection related to higher $R \& D$ intensity. While the authors find a positive correlation between the IP rights index and R\&D intensity, the study makes no attempt to explore the potential endogeneity of the relationship as higher levels of IP protection might drive higher levels of R\&D spending and vice versa. The potential endogeneity is investigated directly in Kanwar and Evenson (2009) for a similar sample of forty-four developed and developing countries (1981-2000). To account for potential endogeneity of R\&D intensity in their regression of the patent rights index on R\&D intensity, Kanwar and Evenson (2009) use three instruments: (i) one period lagged scientific and engineering journal publications, (ii) the percentage gross enrollment rate in tertiary education and (iii) in secondary education. The authors argue that these instruments are valid when also controlling for per capita income and education levels in the equation of interest. ${ }^{14}$ Comparing the results obtained using a specification with and without instruments, Kanwar and Evenson cannot reject equality of the estimates, suggesting exogeneity of the R\&D intensity variable. Moreover, Kanwar and Evenson (2009) do not find a robust correlation between R\&D intensity and IP strength.

Chen and Puttitanum (2005) look at sixty-four developing countries during the 1975-2000 period, using a two equation model where the strength of IPRs is a function of the development level, trade openness, economic freedom, membership in the WTO, whereas innovation (proxied by patenting at the US Patent Office) is a function of IPR strength, development level (GDP per capita), economic freedom, and population. Thus, the instruments for IPR strength are confined to trade openness and WTO membership, which makes identification rather weak. Nevertheless, they show that IPRs have a positive effect on innovation and also that there is a U-shaped relationship between IP strength and the level of development, with IP strength first decreasing and then increasing. Because they included a quadratic for GDP per capita in the IPR equation but not in the innovation equation they cannot say whether the innovation-IP relationship is also U-shaped.

Qian (2007) performs a thorough analysis of the effects of introducing pharmaceutical product patents in eighty-five countries during the years 1978-1999 using matched samples and fixed country-effect estimation. She finds that national patent protection does not stimulate domestic innovation activities except at higher development levels, and that above a certain level of patent protection, innovation activities are actually reduced. McCalman (2001) develops a growth model of bilateral technology transfer and tries to quantify the welfare effects of patent harmonization due to the TRIPS agreement. He finds

\footnotetext{
${ }^{14}$ An overidentification test suggests exogeneity of the instruments. However, the test can only indicate validity of a subset of the instruments and not of all three instruments.
} 
large transfers to the U.S. from developing countries, and also from Canada, the UK, and Japan.

A few conclusions have emerged from this body of work. First, introducing or strengthening a patent system (lengthening the patent term, broadening subject matter coverage or available scope, improving enforcement) results in an increase in patenting and also in the use of patents as a tool of firm strategy (Lerner, 2002; Hall and Ziedonis, 2001), although there is some evidence that the opposite is the case at very low levels of IPR protection (Allred and Park, 2007). This is to be expected, but it is much less clear that these changes result in an increase in innovative activity (Lerner, 2002), although they may redirect energies toward patentable activities and away from those that can be kept secret within the firm (Moser, 2005). ${ }^{15} \mathrm{~A}$ third finding from the empirical literature is that if there is an increase in innovation due to patents, it is likely to be centered in the pharmaceutical, biotechnology, and medical instrument areas, and possibly specialty chemicals. ${ }^{16}$ Yet evidence provided by Wright and Shih (2010) and Lei et al. (2009) for the agricultural biotechnology sector in the U.S. cautions that the overall effect of stronger IPR protection on innovation may be negative.

Fourth and finally, the existence and strength of the patent system affects the organization of industry by allowing trade in knowledge, which facilitates the vertical disintegration of knowledge-based industries and the entry of new firms that possess only intangible assets (Hall and Ziedonis, 2001; Arora et al., 2003; Arora and Merges, 2004). The argument is that by creating a strong property right for the intangible asset, the patent system enables activities that formerly had to be kept within the firm because of secrecy and contracting problems to move out into separate entities. Although limited to two (large) sectors, research supports this conclusion in the chemical and semiconductor industries.

\subsection{Case Studies}

The case study evidence on innovation and development is somewhat mixed. For example, Western Europe, and in particular the UK and Germany, had patent protection during most

\footnotetext{
${ }^{15}$ Wright and Shih (2010) provide an example of how a significant strengthening of IPRs in agricultural biotechnology in the US during the 1980s has led to an increase in private investment in applied research, but has had a negative impact on basic public research. Wright and Shih (2010) argue that the possibility to protect plant varieties has led to a narrow focus on applied research in private sector investment. Patentability also led to a proliferation of fragmented IPRs in this technology field which caused the industry to concentrate to avoid costly IPR sharing. Due to its applied character, private sector investment still relies on public basic research. Wright and Shih (2010), however, report that scattered upstream IPRs impede access to research inputs needed in publicly funded downstream research. Lei et al. (2009) make the important point that IPRs as such are not responsible for this lock-in effect. On the one hand, their survey among academic agricultural biologists reveals that academic scientists find it increasingly difficult to innovate because of IPRs, mostly due to material transfer agreements (MTAs). On the other hand, Lei et al. (2009) point out that IPR protection is an obstacle principally because "it induces institutional administrators, whose financial priorities scientists do not generally share, to encourage or mandate the use of MTAs in exchange of such tools." (Lei et al., 2009: 39).

16 This conclusion relies mostly on survey evidence from a number of countries which shows rather conclusively that patents are not among the most important means to appropriate returns to innovation, except perhaps in pharmaceuticals, medical devices, biotechnology, and some specialty chemicals (Mansfield, 1986; Levin et al., 1987; Cohen et al., 2001; Arora et al., 2001; Graham et al., 2010).
} 
of the industrial revolution, and there were some episodes where such protection appeared to slow rather than hasten technological change (Kanefsky, 1978, as cited by Nuvolari, 2001). Episodes of invention and innovation without patents also existed. ${ }^{17}$ The German chemical industry in the nineteenth-century experienced robust growth during a period when patents were available on processes but not on products (Murmann, 2003). Allen (2006) also provides evidence suggesting that the invention and fast diffusion of machines during the industrial revolution were the result of a combination of relatively high wages and cheap energy in Britain. This created incentives to substitute energy for labor through inventions biased towards saving labor. Allen (2006) suggests that while patents may have played a role in providing incentives to inventors, the main driver of the inventions during the industrial revolution in Britain were relative factor prices rather than changes in the IP system. This idea of induced technological change, i.e., changes in relative factor prices inducing technological change to reduce the input of the relatively more expensive factor, goes back to Hicks (1932). In fact, Allen (2006) points out that the enactment of the English patent law in 1624 before the onset of the industrial revolution appears to have had little impact on innovation in the seventeenth-century.

Several authors have pointed to the fact that a number of successful cases of technological development appear to have taken place in the absence of strong patent protection until a certain level had been reached. The United States did not have national treatment of foreign patent applicants until the signing of the Paris convention in 1883, and domestic inventors were therefore free to copy inventions from the U.K., among others, during most of the nineteenth century. This encouraged local technology development and learning by imitation. Taiwan has followed a similar pattern, with little use of IP protection, especially internationally, until innovators in the country had developed a successful imitation strategy. Taiwanese inventors only began patenting at the USPTO in 1975 and then significantly increased their patenting in 1985.

As Kim $(2002,6)$ says in summarizing his review of Korean technological development:

strong IPR protection will hinder rather than facilitate technology transfer and indigenous learning activities in the early stage of industrialization when learning takes place through reverse engineering and duplicative imitation of mature foreign products. It is "only after countries have accumulated sufficient indigenous capabilities with extensive science and technology infrastructure to undertake creative imitation in the later stage that IPR protection becomes an important element in technology transfer and industrial activities."

It is noteworthy that Korea joined the Paris convention only in 1981, greatly strengthening its patent and copyright laws in 1986, and that patenting by Korean inventors in the United States increased significantly only in 1988 (Kumar, 2003).

In Japan, the story is not as clear. Japan has had a patent system since the nineteenth century. After defeat in World War II, a patent system of one claim per patent that allowed

\footnotetext{
${ }^{17}$ For examples, see Foray and Hilaire-Perez (2001) on the Lyons silk weaving cooperative, Allen (1983) on the iron industry of Cleveland (UK) over the period 1850-1875, and Nuvolari (2001) on the cooperative incremental development of Cornish pumping equipment (a policy that was a response to the mine owners' experience with aggressive patent enforcement by Watt).
} 
for utility models, pre-grant opposition, and early disclosure clearly designed for incremental and or adaptive invention was in place. In addition, the Ministry of International Trade and Industry took an active role in negotiating technology transfer licensing agreements from foreign firms, and during the same period incoming FDI faced difficulties (Maskus, 2004). La Croix and Kawaura (1996) point out that the introduction of pharmaceutical product patents in 1975 in Japan did increase R\&D in that sector. Sakakibara and Branstetter (2001) show that the strengthening of the Japanese patent system in 1988-1993 did not result in increased R\&D spending by Japanese firms, and Branstetter and Nakamura (2003) report that further reforms in the 1990s did not increase innovative performance (measured as the productivity of $R \& D$ ) either.

Kumar (2003) provides an overview of the historical relationship between IPRs, technology, and economic development in the East Asian countries, and his study reaches much the same conclusions as Kim (2002): "Japan, Korea, and Taiwan have absorbed substantial amounts of technological learning under a weak IPR protection regime during the early phases."

Ryan (2010) reaches a different conclusion for his case studies in the bio-medical sector in Brazil. Brazil represents an interesting setting to study the effect of the presence of patents on technology development as it introduced product patents on pharmaceuticals only in 1996. Ryan concludes from the study of five innovation projects in the bio-medical industry that the introduction of pharmaceutical product patents has led domestic companies to invest in the development of new drugs and thus promoted domestic innovation. However, Ryan shows that cooperation with public sector research institutions was crucial in allowing private firms to innovate. He also finds that existing experience with manufacturing generics was very helpful for the firms when the patent regime changed to one where innovative new products were favored.

Finally, Léger (2005) investigates the role of IPRs in the maize breeding industry in Mexico. IPRs relevant to this industry include patents, plant breeders' rights, and trademarks. Through interviews with twenty-five breeders representing the population in the industry, Léger finds an extremely low use of IPRs in the industry. Her qualitative evidence gathered through interviews with breeders suggests that the low use of IPRs is due to a lack of information on the IP system among local breeders, high perceived costs associated with obtaining IPRs, as well as difficulties enforcing the rights. As a result, local breeders do not perceive IPRs to increase incentives for R\&D. In contrast, IPRs were found to be more important to multinational companies and are thought to provide incentives to foreign breeders to adapt technologies to Mexican needs.

In conclusion, the literature on the link between IP and domestic development of technology does not lead to a clear conclusion. While there exists some coherent evidence pointing to the importance of IPRs for domestic innovation, especially in certain industries, there is also convincing (historical) evidence questioning the robustness of this relationship. 


\section{Implications for Climate-Related Technologies}

This section of the paper discusses climate change-related technology development and transfer from developed to developing countries. The global public good character of environmental protection adds another layer of complexity to the issue of IP protection and technology development and transfer discussed so far. The double externality involved in climate change-related technologies implies that additional policy intervention is necessary. This section, therefore, also discusses different forms of policy intervention targeted at the environmental externality, notably market-based regulations such as carbon taxes and top-down interventions like mandatory renewable energy shares in total energy consumption or the replacement of incandescent light bulbs with energy-saving or halogen light bulbs.

\subsection{The Challenge of Climate Change}

While current estimates differ, there is broad consensus that the world-wide expected welfare loss in terms of GDP due to climate change is substantial (Stern, 2006). Existing figures suggest that drastic reductions in carbon emission levels are needed within the current century to keep global warming below the critical level of an average of $2^{\circ} \mathrm{C}$ over pre-industrial revolution levels (Popp, 2010).

World-wide average estimates, however, mask enormous heterogeneity across and within countries (Yohe and Schlesinger, 2002). Tol (2009) reviews a number of recent estimates of the expected impact of climate change on GDP and shows that developing countries represent by far the most heavily affected regions. The differences in welfare losses between developed and developing countries among the estimates reported in Tol (2009) vary between 2.9 percentage points (Hope, 2006) and 36.4 percentage points (Rehdanz and Maddison, 2005). ${ }^{18}$ Some of the studies reviewed in Tol (2009) even suggest small net benefits from moderate global warming of the order $1-2^{\circ} \mathrm{C}$ for some industrialized economies. This enormous inequality in the consequences of climate change between developed and developing countries results mostly from the climatic conditions prevailing in developing countries that will deteriorate disproportionately more as a consequence of even moderate increases in average temperatures. However, part of the vulnerability to climate change stems also from developing countries' reliance on the agricultural sector and less ability to adapt to climate change due to a lack of appropriate technologies.

The main challenge in providing incentives for the development and transfer of green technologies is the double externality problem discussed in the introduction. In addition, the development and adoption of green technologies may involve large sunk costs paired with long time lags in pay-back thresholds, as well as a large amount of uncertainty about future price developments and regulatory changes. The relevant question is whether IP protection - at least partially - addresses these issues.

\footnotetext{
${ }^{18}$ There is a large body of literature analyzing the impact of climate change on specific developing countries suggesting potentially large welfare losses, although outcomes vary substantially depending on the assumptions made on the extent of climate change reflecting the prevailing uncertainty in this context. The considerable projected income losses in developing countries are to a significant extent explained by their dependency on the agricultural sector, which is most directly affected by climate change (Winters et al., 1998).
} 


\subsection{Climate Change-Related Technologies}

Climate change is ascribed to the emission of greenhouse gases which include long-lived gases such as carbon dioxide $\left(\mathrm{CO}_{2}\right)$, methane $\left(\mathrm{CH}_{4}\right)$, and nitrous oxide $\left(\mathrm{N}_{2} \mathrm{O}\right)$ as well as short-lived gases such as water vapor and ozone $\left(\mathrm{O}_{3}\right)$. The most important greenhouse gas by volume is $\mathrm{CO}_{2}$, which is emitted during the fossil fuel combustion process.

The dramatic reduction in carbon emissions needed to counter climate change can be achieved through reduced energy consumption per unit of output holding current technologies fixed (energy efficiency) and the introduction of new technologies that lower carbon emissions per unit of energy consumed holding energy use fixed (carbon efficiency). The most promising path is to combine both a reduction in energy consumption and the introduction of new technologies requiring less energy for the same output. An alternative is to reduce emissions by reducing total economic activity, holding energy and carbon efficiency constant. ${ }^{19}$ Since this alternative is undesirable, in particular to developing countries, the development and diffusion of technologies that allow increasing both energy and carbon efficiency is needed. Note that achieving the proper balance between these two is something for which the price system (carbon taxes or tradable emissions permits) is well-suited, in that it would allow individual consumers to signal their preferences.

Green technologies cover a broad range of fundamentally different types of innovation, including alternative energy resources, technologies employing alternative energy sources, energy storage, distribution and management technologies, recycling and waste technologies, industrial processes, and technologies for capture, storage, and sequestration or disposal of greenhouse gases (Popp, 2010). The underlying technology behind green innovations differ greatly, and range from high-tech innovation such as genetically modified crops to low-tech innovations such as mechanical farming techniques. These technologies differ in other ways as well, for example the fixed costs of innovation and adoption involved and their applicability across industries and climatic zones. Also, the degree to which IPRs are relevant varies considerably over the broad range of green technologies. Whereas inventions in some technological fields, such as biotechnology, rely to a large extent on patenting, other technologies like irrigation systems or construction techniques may be largely free of patenting. ${ }^{20}$ For some technologies, IPRs may protect only components of a technology while for others, IPRs protect the end-product. Similar to the agricultural sector, the need for local adaptation of green technologies to extremely heterogeneous local conditions may also limit the effect of IPRs. Wright and Shih (2010), for example, report that even in agricultural biotechnology where strong IPRs exist, heterogeneity of technology users across space has limited firms'ability to charge high mark-ups.

\footnotetext{
${ }^{19}$ Gans (2010) uses an endogenous growth model to show that under some conditions even policies targeted towards energy efficiency or carbon reductions can reduce overall output enough to discourage environmentally friendly innovation.

${ }^{20}$ Smithers and Blay-Palmer (2001), for example, look at how soybean growers in Ontario, Canada have adapted to climate change by employing mechanical and biological innovations. Smithers and Blay-Palmer point out that most mechanical technologies are not protected by IP rights, only more recent modifications of existing technologies are.
} 
Apart from potentially different technologies needed in developed and developing countries, developed countries mainly face the problem of replacing existing technology with technology that is more carbon/energy efficient. In developing countries, the challenge consists largely in implementing green technologies from the outset. This distinction may lead to different incentives for the adoption of new green technologies. In particular, the benefit-cost trade-off may be more favorable in developing countries due to lower sunk (switching) costs.

\subsection{Climate Change-Related Policy Intervention}

Given the double externality problem, a combination of policy interventions that address both the imperfect appropriability and the environmental externality are needed. Policy intervention can affect relative prices and quantities or directly mandate the use of emission-reducing technologies. Nordhaus (2009) provides a summary of the implications of economic analysis for climate change policies overall. His message is that the only reliable way to send the correct signals to the many agents whose actions affect global warming (innovators, producers, and consumers) is a carbon tax, and that such a tax leads to undesirable effects unless it is global. He argues that the cap and trade system does not send reliable price signals because it induces too much fluctuation in the pricing of emissions, and it is also subject to excessive rent-seeking. However, it has become clear that even if such a tax is the most desirable policy option, it is going to be very difficult to achieve. This is the background to the more specific policies that we consider here.

Most such specific policy interventions have the primary objective of limiting carbon emissions, which addresses the environmental externality directly. By doing so, they also provide incentives for the development and diffusion of green technologies, indirectly addressing the knowledge spillover externality. Such induced innovation can be achieved through a large range of regulatory policies, the broadest of which are emission taxes and the so called cap-and-trade scheme, where a limit on total emissions is set and tradable emission rights are sold. ${ }^{21}$ Top-down regulations include emissions performance standards, which set an emission target but no specific regulations about how a target should be met, such as renewable portfolio standards or restrictions on the use of technologies such as on incandescent light bulbs. Other forms of top-down regulation include climate change mitigation such as reforestation. Regulatory interventions can be local or global in scale. Global harmonization of regulations can give rise to scale effects and thus provide multiplier effects (World Bank, 2010).

There are also policy interventions targeting the development of technologies more broadly in the form of R\&D incentive schemes, for example subsidies and tax credits. If these policies favor green technologies, in principle they can address both the knowledge spillover and environmental externality. Popp (2010) argues that R\&D subsidies serve as an incentive to develop green technologies while regulatory policies are essential in promoting the diffusion of the new technologies. Thus, specific R\&D incentives should be applied in tandem with regulatory policies; such combined policy intervention is particularly important for technologies that only achieve improved carbon efficiency

\footnotetext{
${ }^{21}$ See Scotchmer (2009) for a theoretical comparison of the relative effectiveness of emissions taxes and the cap-and-trade regulation.
} 
without increasing energy efficiency, in which case social benefits exceed private benefits by far. An example is carbon control equipment such as catalytic converters for automobiles.

While such R\&D incentive schemes may be effective in promoting the development of green technology, there is some concern that increased $R \& D$ expenditure on green technology may crowd out other R\&D expenditure and therefore lead to an ambiguous net welfare outcome. In general equilibrium of course, the crowding out is welfare-enhancing by design - by fully incorporating the social welfare cost of environmental degradation in the incentives for $R \& D$ directions, policy-makers have ensured that $R \& D$ directed towards green technologies is valued more by society than other R\&D. But in the short run, there are some effects that make the general equilibrium outcome harder to achieve. These include a lack of scientists and engineers needed for increased R\&D spending and a concomitant rise in their wages (David and Hall, 2000; Goolsbee, 1998), or a lack of scientists and engineers with the relevant expertise. The opportunity cost of climate change-related R\&D (and that of processing and administering IPRs) is particularly relevant to developing countries where resources are heavily constrained.

Popp (2004) provides evidence that even in the presence of substantial crowding out, there are net social benefits from climate change-related R\&D. Gerlagh (2008) provides an explanation for Popp's findings showing that increased R\&D on green technology mostly crowds out R\&D devoted to carbon-producing technologies rather than other carbon neutral R\&D. These results are echoed by Popp and Newell (2009) at the firm-level. These authors confirm that crowding out occurs mostly for innovations enhancing the productivity of fossil fuels. However, as Nordhaus (2009) points out, an appropriate carbon tax can send the right signals for clean technology development and would allow for the preservation of neutrality in any R\&D subsidies.

There is some empirical evidence from developing countries on the effectiveness of policy interventions in promoting green technologies. Fisher-Vanden et al. (2006) investigate the increase in energy efficiency and drop in total energy consumption in China during the period 1997-1999 using a panel of 2,582 large and medium-sized Chinese firms. Apart from shifts in output across industries, the authors find evidence that increases in energy prices as well as the development of new technologies measured as R\&D expenditure account for the drop in energy intensity and use. Although the analysis does not single out the effect of increased energy prices as a consequence of the elimination of state-set energy prices on firm-level R\&D expenditures, it may be suspected that the negative association between energy intensity and R\&D expenditures found by Fisher-Vanden et al. (2006) reflects firms' innovative responses to increased energy prices. Evidence for a positive correlation between energy prices and innovation has also been found in the U.S. by Popp (2002), and at a more aggregate level by Dechezleprêtre et al. (2009), who look at the share of climate change-related patenting in total patents and oil prices over the period 1978-2005.

Jaffe and Palmer (1997) provide some additional insights by looking at the association between costs of complying with environmental regulation and innovation measured as R\&D and U.S. patent applications by U.S. corporations for 2- and 3-digit manufacturing industries in the U.S. Jaffe and Palmer find a positive correlation between lagged environmental compliance expenditures and $R \& D$, although they find no statistically 
significant correlation between compliance expenditures and patenting. The authors suggest that a possible explanation for their findings is that environmental regulations lead to incremental R\&D which does not lead to patentable research output. This would imply that environmental regulation triggers $R \& D$ that is tailored towards complying with the regulations, rather than the invention of genuinely new technologies. However, this study is an aggregate industry level study, with identification coming from the time series behavior of the key variables. Thus, strong conclusions are not warranted, as the authors are careful to point out.

The international nature of the environmental externality increases the complexity of policy regulation considerably. If international differences in regulatory stringency and enforcement exist, incentives arise for pollution-intensive companies to conduct their activities where environmental regulations are least costly. Dean et al. (2009) use data on FDI in the form of equity joint ventures in the manufacturing sector in China for the period 1993-1996 to investigate whether differences in de facto environmental regulations have an impact on foreign investors' location choice within China, since environmental stringency varies across Chinese provinces. Dean et al. construct a measure of regulatory stringency based on the average collected levy per ton of wastewater at the province level. They find that projects in high-pollution sectors by investors from Hong Kong, Macao, Taiwan, Malaysia, Indonesia, and the Philippines avoid provinces with high pollution taxes. Projects from investors such as the U.S., E.U. and Japan do not appear to respond to environmental regulatory stringency in their location choice. The interpretation is that firms from developed economies employ greener technologies and are therefore less sensitive to environmental levies. Still, this does not imply that firms located in OECD countries do not react to domestic environmental regulation by re-locating production. For example Hanna (2010) shows that US-based multinationals reacted to increased environmental regulatory stringency introduced by the Clean Air Act Amendments in the U.S. by expanding existing FDI activities abroad, albeit not disproportionately more so in developing countries.

\subsection{Climate Change-Related Technology Development}

To answer the question of whether IP rights hinder the development and transfer of green technologies, a report by Copenhagen Economics (2009, commissioned by the European Commission) analyzes patent data for seven green technology fields for a sample of thirtyeight developing and emerging countries over the period 1998-2008. ${ }^{22}$ The study notes a strong increase in green technology patent counts designating a small group of emerging economies including Brazil, China, and India. The increase in green technology patents designating these countries is in solar energy, fuel cells, and wind energy. However, in the least-developed countries included in the sample, patents for green technologies are absent, as are patents in general. The absence of patents on green technologies in the leastdeveloped countries leads the report to conclude that IPRs do not represent a barrier to the development and transfer of green technology in the least developed countries. However, one could argue equally well that the absence of these patents means that firms do not view

\footnotetext{
${ }^{22}$ The technologies are wind, solar energy, fuel cell, geothermal, ocean, biomass and waste.
} 
the countries as profitable markets for green technology innovations. One possible explanation for the absence of IPRs in these countries is their reliance on low-tech innovations. If these low-tech innovations correspond to the environmental challenges in these countries, this suggests that the low patent counts found for green technologies are not the result of market failure and that there is no specific role for IPRs in this context. ${ }^{23}$

Lanjouw and Mody (1995) look at the distribution of climate change-related patents for seventeen countries, including OECD members and a heterogeneous set of low- and middle-income countries. ${ }^{24}$ They find a large concentration of climate change-related patents among Japan, U.S., and Germany. ${ }^{25}$ Given the time period analyzed, 1971-1988, China still lags far behind, although the number of environmental patents granted in Brazil is already noticeable. Dechezleprêtre et al. (2009) extend the work by Lanjouw and Mody and use a more a comprehensive database (PATSTAT) to investigate in more detail the geographical distribution of inventions in thirteen climate change-related technologies between 1978 and $2005 .{ }^{26}$ The authors use patent families as a measure for domestic inventions and patents of the same family as a measure of technology transfer where the country of residence of the inventors of the first patent application is regarded as the originating country of the technology.

Similarly to Lanjouw and Mody, Dechezlepretre et al. (2009) use the PATSTAT data and find that the overwhelming share of inventors of granted patents between 1978 and 2003 reside in Japan, the U.S., and Germany, and account together for nearly sixty percent of all patents in the chosen technological fields. China is the only developing country within the top ten countries, accounting for a share of eight percent of patents. However, it is worth noting that inventors in the top three countries account for eighty-two per cent of USPTO patents overall during this period, while China accounts for less than one per cent, so that in fact climate change-related patenting is probably less concentrated than patenting as a whole.

How should these results be interpreted? The insights that can be gained from studies such as Lanjouw and Mody (1995) and Dechezleprêtre et al. (2009) are limited because they can only describe patenting patterns that are the outcome of the interaction of a range of factors and do not shed light on the causal determinants of the observed patent counts and their geographical distribution. However, they do suggest that technological change in this area may be more widely dispersed than in other areas, probably reflecting the fact that it is a relatively recent area of innovation in which some developing countries benefit from

\footnotetext{
${ }^{23}$ Shafik (1994) provides cross-country evidence for a panel of 149 countries over the period 1960-1990 suggesting that countries tackle different environmental problems at different stages of their development. Hence, Shafik suggests that less developed economies might be less interested in patented frontier technologies than emerging economies.

${ }^{24}$ The technological fields are industrial and vehicular air pollution, water pollution, hazardous and solid waste disposal, incineration and recycling of waste, oil spill clean-up, and alternative energy.

${ }^{25}$ As discussed further below, eighty-two per cent of all USPTO patents granted between 1971 and 1988 were held by inventors in these three countries, so this result is not surprising.

${ }^{26}$ These are wind, solar, geothermal, marine energy, biomass, hydropower, waste-to-energy, methane destruction, climate-friendly cement, thermal insulation in buildings, heating, electric and hybrid vehicles, and energy efficient lighting.
} 
geographical advantages. Another important issue regards the identification of patents covering climate change-related technologies. There are substantial differences in the definition of the relevant technology classes across the different studies discussed above. ${ }^{27}$ In part, differences are accounted by changes in the IPC system and relevant technologies over time; yet, some arbitrariness remains making comparisons of results across the different studies difficult.

Popp (2001) looks directly at the association between energy patents and energy consumption for the U.S. between 1959 and 1991. He finds negative elasticities of energy consumption with respect to energy patents in eight out of thirteen manufacturing sectors. When combined with findings by Popp (2002) that show a positive elasticity of the share of energy patents in total patents with respect to energy prices, these results suggest that an increase in energy prices induces innovation measured as patent counts which are negatively correlated with energy consumption. This research, therefore, suggests that there is a positive correlation between energy prices, green patenting, and a fall in energy consumption.

There are several conclusions that can be drawn from our discussion. First, while there is a growing body of literature on the determinants of the development of green technologies focusing on the range of available policy interventions, the existing literature specifically addressing the link between IPRs and the development of climate change-related technologies is surprisingly small, and it is even more so with regard to developing countries. Second, the sparse existing evidence suggests above all that there is substantial heterogeneity amongst developing countries. A small number of countries, above all Brazil, China, India, and Mexico, are engaging in the development of green technologies and gaining a noticeableshare in the worldwide technology market for certain technologies, mostly in the area of renewable energies. Since these countries also have strengthened their IP systems in the recent past, it may be tempting to conclude that there is a positive relationship between IPRs and the development of climate change-related technologies. This conclusion, however, is not warranted based on the available evidence, as this relationship may be confounded with a whole range of other factors. Work from the U.S., however, suggests that there may exist a positive association between green technology patents and reductions in energy consumption.

\subsection{Climate Change-Related Technology Transfer}

Similar to the development of green technologies discussed in the preceding section, the diffusion of technologies that merely achieve improved carbon efficiency without increasing energy efficiency will not occur without some form of regulation or subsidy (Snyder et al., 2003). In contrast, technologies increasing energy efficiency may be adopted and diffused without policy intervention as private benefits may exceed private costs (Rose and Joskow, 1990). Yet diffusion may still be suboptimal from a social perspective if the cost of adoption does not factor in social benefits. Diffusion may also not occur in the presence of market failures and behavioral biases in decision-making (Gillingham et al., 2009). Indeed, it has been observed that diffusion of green technologies

\footnotetext{
${ }^{27}$ Technologies are identified by patents' IPCs (International Patent Classification) which represent a patent and utility model specific technology-oriented classification system.
} 
is lower than a comparison of private costs and benefits would suggest. There are several explanations for the so called "energy efficiency paradox" (Jaffe and Stavins, 1994). These are high discount rates used by consumers, large up-front fixed costs, credit constraints, agency problems and uncertainty about future price developments.

While there exist a number of studies on international technology transfer from developed to developing countries, "compared to the more general literature on international technology transfer, applications pertaining to the environment are scarce" (Popp et al., $2009,50)$, and even scarcer when it comes to developing countries.

Lanjouw and Mody (1995) find in their analysis of climate change-related patents for seventeen OECD and developing countries substantial evidence that technology transfer occurs from developed to developing countries, but not in the other direction, since very few patents in OECD countries are granted to developing countries. At the same time, Lanjouw and Mody find that a non-negligible share of patents in developing countries are granted to domestic inventors. Interpreting the evidence, Lanjouw and Mody suggest that developing countries engage mostly in adaptation of technologies transferred from OECD countries. This interpretation is confirmed by assessing the importance of patents granted to OECD inventors in developing countries. Using citation data and family size as measures of a patent's importance, Lanjouw and Mody find that patents granted to OECD inventors in developing countries are of a broad nature and most likely not tailored to local needs. In their similar, albeit more recent analysis of global patenting in climate changerelated technology fields, Dechezleprêtre et al. (2009) show that most technology transfer in green technologies occurs within OECD countries. Among non-OECD countries, only China registered a noteworthy share of patent filings by OECD applicants. These results should be interpreted with caution as Lanjouw and Mody $(1996,561)$ note that the "extent of foreign patenting is a crude measure of technology transfer."

Barton (2007) chooses instead a case study-based approach looking specifically at three specific sectors (photo-voltaic, bio-mass, and wind energy) in Brazil, China, and India. $\mathrm{He}$ finds IPRs to have little impact on technology transfer in these sectors. Barton suggests that competition among technology suppliers within the three technological fields analyzed act as an effective constraint to firms' attempts to exploit their patent rights. At the same time, the prevailing oligopolistic market structure poses a risk for collusion and thus a barrier to entry for new small firms, which, according to Barton (2007), represents a more important threat to technology development than IPRs. However, Barton notes that in the area of wind energy, there exists some evidence for firms using their patents as a strategic competitive tool and there is also some risk that new broad patents might hinder future innovation.

The United Nations Framework Convention on Climate Change (UNFCCC) and its Kyoto Protocol also introduced market-based interventions designed to promote technology transfer between developing and developed countries (so called Annex 1 countries) ${ }^{28,29}$

\footnotetext{
${ }^{28}$ Annex 1 countries are developed countries and countries in transition, including the members of the European Union, Iceland, Norway, Switzerland, Canada, Australia, New Zealand, Japan, the U.S., Turkey, Belarus, Ukraine, and the Russian Federation. Annex 2 countries are the developed country subset of this grouping.
} 
The Clean Development Mechanism (CDM) allows polluters in developed countries to receive Certified Emission Reduction (CER) credit for undertaking projects in developing countries that reduce emissions and is regarded as "one of the most innovative tools of the Kyoto Protocol" (Dechezleprêtre et al., 2008, 1273). Firms in developed countries have incentives to engage in the CDM, as it is usually cheaper to achieve required emission reductions in developing countries. However, the incentives provided by CDM go beyond the cheaper fulfillment of emission reductions as it allows firms to engage in new markets. For example, Costa et al. (2008) provide case study evidence for the Dutch waste management industry showing that firms not subject to emission limits also engage in CDM projects. While allowing developed countries to achieve emission targets at reduced cost, the CDM is designed to lead not only to embodied, but also to disembodied technology transfer to developing countries. The CDM scheme, therefore, offers an opportunity to analyze the extent of existing technology transfer between developed and developing countries.

Dechezleprêtre et al. (2008) uses a dataset of 644 CDM projects to investigate the extent of technology transfer occurring through the CDM scheme. The authors find that only fortythree percent of all projects include some form of technology transfer component, although these projects account for eighty-four percent of total expected annual $\mathrm{CO}_{2}$ emission reductions by all projects. Thirty-four percent of projects include disembodied technology transfer. They also show that the share of projects including technology transfer varies substantially across technology classes. With regard to the geographical distribution of the CDM projects, Dechezleprêtre et al. find a strong concentration (seventy-three percent) in Brazil, China, India and Mexico. Nevertheless, there is also substantial heterogeneity within this group, as fifty-nine percent of Chinese projects involve technology transfer but only twelve percent of Indian projects. Unfortunately, Dechezleprêtre et al. (2008) do not relate their data on CDM projects to information on IPRs, except via a technological capability variable provided by Archibugi and Coco (2004) that incorporates previous patenting in the country. This measure yields mixed results across sectors; it is positively correlated with technology transfer in the energy and chemical industries and negatively so in the agricultural sector.

In an analysis of similar data, Doranova et al. (2009) show evidence for a negative correlation between USPTO patenting in climate change-related technologies by a CDM project host country and the probability that the CDM project relies on local technologies instead of transferring foreign technology. Taken at face value, this suggests that countries with patents in climate change-related technologies are more likely to benefit from foreign technology transfer through CDM projects possibly because they are at a more advanced stage of development. A conclusion that can be drawn from the analysis of CDM projects is that there exists considerable heterogeneity among developing countries in attracting CDM projects. However, the analysis is limited in terms of its insights with regard to the role of IPRs in technology transferred in CDM projects.

\footnotetext{
${ }^{29}$ Another mechanism instituted by the Kyoto Protocol promoting technology transfer is the Joint implementation (JI) scheme. However, JI is limited to Annex 1 countries and therefore concerns mostly technology transfer to Eastern European economies from Annex 2 countries (Youngman et al., 2007).
} 
There are also private initiatives that are not directly induced by regulation that promote transfer of green technologies. An example of open access to climate change-related IPRs is the Eco-Patent Commons initiative coordinated by the business association World Business Council for Sustainable Development (WBCSD). ${ }^{30}$ A number of large multinational companies have pledged to grant patents in climate change-related technological fields that can be used without a license. ${ }^{31}$ A quantitative analysis of the effect of putting these patent rights in the public domain on technology development and transfer could shed light on the importance of IPRs for technology transfer in the context of climate change. Of course, a cynic could interpret these patent donations as an indication that the companies do not perceive any profit opportunities from using these patents that are large compared to the public relations benefit from making them available.

Another promising avenue for green technology transfer is the joint projects between private companies, such as the DESERTEC project officially launched in July $2009 .{ }^{32}$ The project envisions the large-scale production of energy through solar thermal power plants and windmills in the deserts of North Africa and the Middle East to supply these regions as well as the EU with renewable energy through a high-voltage direct-current grid connecting these three regions. The project is carried out by a consortium of European and Algerian companies, although it is expected to soon also include Moroccan, Tunisian, and Egyptian firms. An investigation of the role played by patented technologies in the project could deliver additional insights on their effect on international cooperation among firms.

The review of the existing literature on technology transfer in the context of climate change-related technologies provides little conclusive evidence. Studies looking at patenting by foreign companies as a measure of technology transfer suggest that most technology exchange is occurring between OECD countries. Case-study based evidence attributes no significant role to IPRs in transferring technology. The available evidence for the role of patents in promoting technology transfer provides tentative evidence at best for patents fostering technology transfer. Yet, this result is inline with the evidence found in the general literature on the link between IPRs and technology transfer discussed in Section 2.

\section{Conclusion}

The objective of this paper was to review the existing evidence on the link between IPRs and the development and transfer of climate change-related technology. For this purpose, we also reviewed the established literature on the broader nexus between IPRs and development and transfer of technology.

\footnotetext{
${ }^{30} \mathrm{http}: / /$ www.wbcsd.org/web/epc.

${ }^{31}$ As of February 2010, a selection of patents assigned to Bosch, DuPont, Fuji-Xerox, IBM, Nokia, Pitney Bowes, Ricoh, Sony, Taisei, The Dow Chemical Company, and Xerox are available under Eco-Patents Commons.

32 http://www.desertec.org.
} 
The general overview suggests the following conclusions:

- Stronger patent enforcement encourages patenting in general, although it is not clear that the increase in patenting reflects increased underlying innovation or the increased use of patents as a strategic tool. IPR protection may also redirect research to applied and patentable research with potential negative effects for the generation of fundamental drastic innovation.

- Stronger patents encourage technology transfer in the form of imports, FDI, and licensing to developing countries.

- Stronger patents have little effect on technology transfer to the lowest income countries.

- It is difficult to find clear evidence that stronger patents positively impact innovation except in chemical-related sectors including pharmaceuticals. Many other factors matter, so the experiments are often not clear. We do not observe enough variation in patent systems, and there is little evidence on how much time firms need to respond to changes in IPR regimes. It is also rare to have an independent measure of innovation (other than patents) that allows to disentangle changes in innovation and patenting, so ingenuity is required.

Regarding the link between the development of green technologies and IPRs, we draw the following conclusions:

- Climate change-related technologies comprise a vast range of fundamentally different technologies addressing distinct climate change-related problems. Patenting propensities and patent effectiveness differ substantially across different technological fields. This makes it highly unlikely that a single, universal mechanism characterizes the nexus between IPRs and the generation and diffusion of green technologies within countries. Also, since different technologies are appropriate for different countries depending on their location, industrial structure, and stage of development, it is highly unlikely that a single, universal mechanism characterizes the nexus between IPRs and the generation and diffusion of green technologies across countries.

- IPRs can address the gap between private and social returns to innovation that results from the public good characteristics of knowledge. However, IPRs are not designed to remediate environmental externalities. As a result, patent protection offers only a limited instrument for mitigating environmental externalities. Therefore, it may be more conducive to frame the discussion of IPRs and green technology within a setting defined by policy interventions specifically designed to address environmental externalities.

- There are a number of other issues apart from IPRs that are of first-order importance in setting incentives for the development and transfer of technologies, most notably large uncertainty regarding the innovative process of new technologies (Johnson and Lybecker, 2009b). Developing countries themselves may also generate powerful distortions inhibiting the production and transfer of green technologies. A report by Copenhagen Economics (2009) suggests that subsidies for the consumption of fossil fuels in some developing countries, such as Venezuela, Iran and Indonesia, may represent a significant barrier to the 
development and transfer of green technologies in these countries. Barton (2007) suggests that import tariffs on photo-voltaic and wind technology in place in India and China may also act as a barrier to technology development and transfer. In contrast, import tariffs and subsidies for biofuels in place in industrialized countries, above all the E.U. and the U.S., hamper the development of this industry in developing countries, such as Brazil (World Bank, 2010). Similarly, in January 2009 , the U.S. customs agency decided that imports of solar panels to the U.S. should be treated as imports of electric generators and thus subject to a duty of 2.5 percent. Such import barriers on green technologies represent a complex issue because there must be policy interventions in place in developed countries dedicated to market creation (Taylor, 2008) such as subsidies, to promote demand for green technologies produced in developing countries. From a political economy perspective, it is unclear how far developed economies are willing to subsidize demand for green technology from abroad. This problem has already emerged in the case of feed-in price regulation in Germany, which caused a large increase in imported solar panels from China.

- Existing studies using patent counts to describe the geographical distribution of inventors of green technologies and their international transfer are by construction limited in terms of insights they can deliver. While useful in improving our understanding of the patenting distribution in green technologies across sectors, countries and time, these studies cannot deliver an answer to the question of whether IPRs help or hinder the development and transfer of green technologies. Furthermore, to-date there exists no consensus with regard to the definition of relevant technology classes as identified by patents' IPCs. However, any interpretation of results hinges crucially on this definition.

- The limited existing evidence suggests that there are two groups of developing countries. In the first group are emerging economies, such as Brazil, China, India, and Mexico, and in the second group a larger number of less-developed countries. Similar to the conclusion drawn from the general literature on technology development and transfer, the evidence on green technologies suggests that a strengthening of IPRs for the group of emerging economies will most likely have a positive impact on the domestic development of technology and its transfer from developed economies. The available evidence does not allow drawing a similar conclusion in the case of less developed countries.

- On the whole, the existing evidence on the role of IPRs in promoting the development and diffusion of climate change-related technologies is surprisingly sparse and does not provide sufficient insight to reach any substantial conclusion. This calls for additional efforts in investigating the relationship between IPRs and green technologies specifically in developing countries. 


\section{List of References}

Acemoglu, D., P. Aghion, L. Bursztyn, and D. Hemous (2009). The Environment and Directed Technical Change. NBER Working Paper No. 15451.

Agarwal, B. (1983). Diffusion of Rural Innovations: Some Analytical Issues and the Case of Wood-burning Stoves. World Development, 11 (4), 359-76.

Allen, R. C. (1983). Collective Invention. Journal of Economic Behavior and Organization 4 (1), $1-24$.

Allen, R. C. (2006). The British Industrial Revolution in Global Perspective: How Commerce Created The Industrial Revolution and Modern Economic Growth. mimeo Oxford University Department of Economics.

Allred, B. and W. Park (2007). Patent rights and innovative activity: evidence from national and firm-level data. Journal of International Business Studies, 38, 878-900.

Angeles, L. (2005), Should Developing Countries Strengthen their Intellectual Property Rights? BE Journal of Macroeconomics 5 (1), article 23. Available at http://www.bepress.com/bejm/topics/vol5/iss1/art23/

Archibugi, D., and A. Coco (2004). A new indicator of technological capabilities for developed and developing countries. World Development, 32 (4), 629-654.

Arora, A., Ceccagnoli, M. and Cohen, W. (2003). R\&D and the patent premium. Cambridge, MA: NBER Working Paper No. 9431.

Arora, A., Fosfuri, A. and Gambardella, A. (2001). Markets for Technology: The Economics of Innovation and Corporate Strategy. Cambridge, MA: MIT Press.

Arora, A., and R. P. Merges (2004). Specialized Supply Firms, Property Rights, and Firm Boundaries. Industrial and Corporate Change 13, 451-475.

Arora, A., and M. Ceccagnoli (2006). Patent Protection, Complementary Assets, and Firms' Incentives for Technology Licensing. Management Science, 52 (2), 293-308.

Arora, A. and A. Gambardella (2010). Implications for Energy Innovation from the chemical industry. NBER Working Papers 15676, National Bureau of Economic Research.

Awokuse, T.O. and H. Yin (2010). More Bilateral Trade? Evidence from China's Imports. World Development, in press.

Barnes, D. F., K. Openshaw, K.R. Smith and R. van der Plas (1993). The Design and Diffusion of Improved Cooking Stoves. World Bank Research Observer, 8 (2), 119-141

Barton, J. H. (2007). Intellectual Property and Access to Clean Energy Technologies in Developing Countries. ICTSD Issue Paper No. 2.

Branstetter, L. G. (2004). Do Stronger Patents Induce More Local Innovation? Journal of International Economic Law 7(2), pp. 359-70.

Branstetter, L. G., R. Fisman, and C. F. Foley (2006). Do Stronger Intellectual Property Rights Increase International Technology Transfer? Empirical Evidence from U.S. Firm-Level Panel Data. Quarterly Journal of Economics 121 (1), 321-349.

Branstetter, L. G., and Y. Nakamura (2003). Is Japan's Innovative Capacity in Decline? In Blomström, M. (ed.), Structural impediments to growth in Japan. Chicago, IL: University of Chicago Press. Also National Bureau of Economic Research Working Paper Series No. 9438. 
Chen, Y. (2008). Why Do Multinational Corporations Locate Their Advanced R\&D Centres in Beijing? Journal of Development Studies, 44 (5), 622-644.

Chen, Y., and T. Puttitanum (2005). Intellectual Property Rights and Innovation in Developing Countries. Journal of Development Economics, 78 (2), 474-493.

Chin, J., and G. Grossman (1990). Intellectual property rights and north-south trade. In: Jones, R., and A. Krueger (Eds.), The Political Economy of International Trade. Basil Blackwell, Cambridge.

Cohen, W. M., Goto, A., Nagata, A., Nelson, R. R. and Walsh, J. P. (2002). R\&D spillovers, patents and the incentives to innovate in Japan and the United States. Research Policy 31, $1349-67$.

Copenhagen Economics A/S and the IPR Company A/S (2009). Are IPRs a Barrier to the Transfer of Climate Change Technology?. Report commissioned by the European Commission (DG Trade).

Costa, I., A. Doranova and G.-J. Eenhoorn (2008). Beyond the emission market: Kyoto and the international expansion of waste management firms. UNU-Merit Working Paper Series \#2008-020.

David, P. A. and B. H. Hall (2000). Heart of Darkness: Public-Private Interactions Inside the R\&D Black Box. Research Policy 29, 1165-1183.

Dean, J. M., M. Lovely, and H. Wang (2009). Are foreign investors attracted to weak environmental regulations? Evaluating the evidence from China. Journal of Development Economics, 90, 1-13.

Deardorff, A.V. (1992). Welfare Effects of Global Patent Protection. Economica, 59 (233), 35-51.

Dechezleprêtre, A., M. Glachant, and Y. Ménière (2008). The Clean Development Mechanism and the international diffusion of technologies: An empirical study. Energy Policy, 36(4), $1273-1283$.

Dechezleprêtre, A., M. Glachant, and, I. Hascic, N. Johnstone and Y. Ménière (2009). Invention and Transfer of Climate Change Mitigation Technologies on a Global Scale: A Study Drawing on Patent Data. Fondazione Eni Enrico Mattei Nota di Lavoror No. 82.2009.

Derclaye, E. (2008). Intellectual Property Rights and Global Warming. Marquette Intellectual Property Law Review, 12:2, 264-297.

Derclaye, E. (2009). Patent law's role in the protection of the environment - re-assessing patent law and its justifications in the 21st century. International Review of Intellectual Property and Competition Law, 4.

Doranova, A., I. Costa and G.-J. Eenhoorn (2009). Knowledge Base Determinants of Technology Sourcing in the Clean Development Mechanism Projects. UNU-Merit Working Paper Series \#2009-015.

Fisher-Vanden, K., G. H. Jefferson, H. Liu, and Q. Tao (2004). What is driving China's decline in energy intensity?. Resource and Energy Economics, 26(1), 77-97.

Foray, D., and L. Hilaire-Perez (2001). The Economics of Open Technology: Collective Organization and Individual Claims in the "Fabrique Lyonnaise" During the Old Regime. In C. Antonelli, D. Foray, B. H. Hall and W. E. Steinmueller (eds.), Essays in Honor of Paul A. David. Cheltenham, UK: Edward Elgar. 
Fosfuri, A. (2004). Determinants of international activity: evidence from the chemical processing industry. Research Policy 33 (10), 1599-1614.

Gans, J. S. (2010). "Innovation and Climate Change Policy." Melbourne, Australia: Melbourne Business School. Available at http://www.mbs.edu/jgans

Gerlagh, R. (2008). A Climate-Change Policy Induced Shift from Innovations in Carbon-Energy Production to Carbon-Energy Savings. Energy Economics, 30, 425-448.

Gillingham, K., R.G. Newell, and K. Palmer (2009). Energy Efficiency Economics and Policy. Annual Review of Resource Economics, 1, 597-620.

Ginarte, J. C., and W. G. Park (1997). Determinants of patent rights: A cross-national study. Research Policy 26 (3), 283-301.

Goolsbee, A. (1998). Does government R\&D policy mainly benefit scientists and engineers? American Economic Review 88(2), 298-302.

Graham, S. J. H., R. P. Merges, P. Samuelson, and T. Sichelman (2010). High Technology Entrepreneurs and the Patent System: Results of the 2008 Berkeley Patent Survey. Berkeley Technology Law Journal 24(4), 1255-1328.

Greenhalgh, C., and M. Rogers (2010). Innovation, Intellectual Property, and Economic Growth. Princeton University Press.

Grossman, G. M. and E. Helpman (1991). Innovation and growth in the global economy. MIT Press.

Grossman, G. M., and E. L.-C. Lai (2004). International Protection of Intellectual Property. American Economic Review 94 (5), 1635-1653.

Hall, B. H. and Ziedonis, R. H. (2001). The patent paradox revisited: an empirical study of patenting in the U.S. semiconductor industry, 1979-1995. RAND Journal of Economics 32, $101-28$.

Hanna, R. (2010). US Environmental Regulation and FDI: Evidence from a Panel of US-Based Multinational Firms. American Economic Journal: Applied Economics, 2, 158-189.

Heal, G. and B. Kriström (2002). Uncertainty and Climate Change. Environmental and Resource Economics, 22, 3-39.

Heald, P. J. (2003). Misreading a canonical work: An analysis of Mansfield's 1994 study. Journal of Intellectual Property Law 10, 309-318.

Hicks, J.R. (1932). The Theory of Wages. MacMillan, London.

Hope, C. W. (2006). The Marginal Impact of CO2 from PAGE2002: An Integrated Assessment Model Incorporating the IPCC's Five Reasons for Concern. Integrated Assessment Journal, 6(1), 19-56.

ICTSD and UNCTAD. (2003). Intellectual Property Rights, Implications for Development Policy. Discussion Paper, Geneva, Switzerland: ICTSD and UNCTAD.

IPCC (2007). Climate Change 2007 - Synthesis Report.

Ito, B. and R. Wakasugi (2007). What factors determine the mode of overseas R\&D by multinationals? Empirical evidence. Research Policy, 36, 1275-1287.

Jaffe, A. B. and R. N. Stavins (1994). The energy paradox and the diffusion of conservation technology. Resource and Energy Economics, 16(2), 91-122 
Jaffe, A. B. and K. Palmer (1997). Environmental Regulation an Innovation: A panel data study. Review of Economics and Statistics, 79(4), 610-619.

Jaffe, A. B., R. G. Newell, and R. N.Stavins (2005). A tale of two market failures: Technology and environmental policy. Ecological Economics, Vol. 54(2-3), 164-174.

Johnson, D. K. and K. M. Lybecker (2009a). Innovating for an Uncertain Market: A Literature Review of the Constraints on Environmental Innovation. Colorado College Working Paper No. 2009-06.

Johnson, D. K. and K. M. Lybecker (2009b). Challenges to Technology Transferr: A Literature Review of the Constraints on Environmental technology Dissemination. Colorado College Working Paper No. 2009-07.

Kanefsky, J. and J. Robey (1980). Steam Engines in 18th-Century Britain: A Quantitative Assessment. Technology and Culture 21 (2), 161-186

Kanwar, S. and R. Evenson (2003). Does Intellectual Property Protection Spur Technical Change? Oxford Economic Papers 55, 235-264.

Kanwar, S. and R. Evenson (2009). On the Strength of Intellectual Property Protection that Nations Provide. Journal of Development Economics, 90, 50-56.

Keller, W. (2010). International Trade, Foreign Direct Investment, and Technology Spillovers. In Hall, B. H. and N. Rosenberg. (eds.), Handbook of the Economics of Innovation. Amsterdam: Elsevier-NorthHolland, pp. 793-829.

Keller, W. (2004). International Technology Diffusion. Journal of Economic Literature. Vol. XLII, $752-782$.

Kim, L. (2002). Technology Transfer and Intellectual Property Rights: The Korean Experience. BRIDGES, ICTSD 6 (8), November-December.

Kumar, N. (2003). Intellectual Property Rights, Technology and Economic Development: Experiences of Asian Countries. Economic and Political Weekly 38 (3), 209-226.

La Croix, S. J. and A. Kawaura (1996). Product Patent Reform And Its Impact On Korea's Pharmaceutical Industry. International Economic Journal 10(1), 109-124,

Lanjouw, J.O. and A. Mody (1996). Innovation and the international diffusion of environmentally responsive technology. Research Policy, 25(4), 549-571.

Lee, J.-Y., and E. Mansfield (1996). Intellectual Property Protection and U.S. Foreign Direct Investment. Review of Economics and Statistics 78 (2), 181-186.

Léger, A. (2005). Intellectual Property Rights in Mexico: Do They Play a Role? World Development 33 (1), 1865-1879.

Lei, Z., R. Juneja, and B. D. Wright (2009). Patents versus patenting: implications of intellectual property protection for biological research. Nature Biotechnology 27 (1), 36-40.

Lerner, J. (2002). Patent Protection and Innovation over 150 Years. American Economic Review 92 (2), 221-225.

Mansfield, E. (1986). Patents and Innovation: An Empirical Study. Management Science 32 (2), 173-181.

Mansfield, E. (1994). Intellectual property protection, foreign direct investment, and technology transfer. Washington, DC: International Finance Corporation Discussion Paper No. 19. 
Mansfield, E. (2000). Intellectual property protection, direct investment and technology transfer: Germany, Japan and the USA. International Journal of Technology Management 19 (1/2), 3-21.

Maskus, K. E. and M. Penubarti (1995). How trade-related are intellectual property rights? Journal of International Economics, 39, 227-48.

Maskus, K. E. (2004). Encouraging International Technology Transfer, Geneva, Switzerland: ICTSD and UNCTAD Issue Paper No. 7.

McCalman, P. (2001). Reaping what you sow: an empirical analysis of international patent harmonization. Journal of International Economics 55 (1), 161-186.

Moser, P. (2005). How Do Patent Laws Influence Innovation? Evidence from Nineteenth-Century World's Fairs. American Economic Review 95 (4), 1214-1236.

Mowery, D. C., R. R. Nelson, and B. Martin (2009). Technology policy and global warming. London, UK: NESTA Provocation 10.

Murmann, J. P. (2003). Knowledge and Competitive Advantage: The Coevolution of Firms, Technology, and National Institutions. New York: Cambridge University Press.

Newell, R. G., A.B. Jaffe, and R. N. Stavins (2006). The effects of economic and policy incentives on carbon mitigation technologies. Energy Economics, Vol. 28(5-6), 563-578.

Nordhaus, W. D. (2009). Economic Issues in a Designing a Global Agreement on Global Warming. Keynote Address at the Climate Change Conference, Copenhagen, Denmark, March 10-12, available at http://nordhaus.econ.yale.edu/documents/Copenhagen 052909.pdf

Nordhaus, W. D. (1969). Invention, Growth, and Welfare: A Theoretical Treatment of Technological Change. MIT Press.

Nuvolari, A. (2001). Collective Invention during the British Industrial Revolution: The Case of the Cornish Pumping Engine. DRUID, Copenhagen Business School Working Paper 01-05.

Park, W. G., and J. C. Ginarte (1997). Intellectual Property Rights and Economic Growth. Contemporary Economic Policy XV (July), 51-61.

Park, W. G. and D. C. Lippoldt (2008). Technology Transfer and the Economic Implications of the Strengthening of Intellectual Property Rights in Developing Countries. OECD Trade Policy Working Papers No. 62.

Penrose, E. (1973). International Patenting and the Less-Developed Countries. Economic Journal, 83 (331), 768-786.

Popp, D. and R.G. Newell (2009). Where Does Energy R\&D Come From? Examining Crowding Out from Environmentally-Friendly R\&D. NBER Working Paper No. 15423.

Popp, D., R.G. Newell, and A. Jaffe (2010). Energy, the Environment, and Technological Change. In Hall, B. H. and N. Rosenberg. (eds.), Handbook of the Economics of Innovation. Amsterdam: Elsevier-NorthHolland, pp. 873-972. Also National Bureau of Economic Research Working Paper Series No. 14832.

Popp, D. (2001).The effect of new technology on energy consumption. Resource and Energy Economics, 23, 215-239.

Popp, D. (2002). Induced innovation and energy prices. American Economic Review, Vol. 92(1), 160-180. 
Popp, D. (2010). Innovation and Climate Policy. National Bureau of Economic Research Working Paper Series No. 15673.

Qian, Y. (2007). Do Additional National Patent Laws Stimulate Domestic Innovation in a Global Patenting Environment. Review of Economics and Statistics 89 (3), 436-453.

Rehdanz, K. and D. J. Maddison (2005). Climate and Happiness. Ecological Economics, 52(1), 111-25.

Rimmer, M. (2009). The road to Copenhagen: intellectual property and climate change. Journal of Intellectual Property Law \& Practice, Advance Access.

Rose N. L. and P. L. Joskow (1990). The Diffusion of New Technologies: Evidence from the Electric Utility Industry. RAND Journal of Economics, 21(3), 354-373.

Ryan, M. (2010). Patent Incentives, Technology Markets, and Public-Private Bio-Medical Innovation Networks in Brazil. World Development, in press.

Sakakibara, M., and L. G. Branstetter (2001). Do Stronger Patents Induce More Innovation? Evidence from the 1988 Japanese Patent Law Reforms. Rand Journal of Economics 32 (1), 77-100.

Scotchmer, S. (2004). The Political Economy of Intellectual Property Treaties. Journal of Law, Economics, and Organization 20 (2), 415-437.

Scotchmer, S. (2009).Cap-and Trade, Emissions Taxes, and Innovation. Mimeo School of Law, University of California, Berkeley.

Shafik, N. (1994). Economic Development and Environmental Quality: An Econometric Analysis. Oxford Economic Papers, Special Issue on Environmental Economics, 46, 757-773.

Smith, P. (1999). Are weak patent rights a barrier to U.S. exports? Journal of International Economics, 48, 151-177.

Smith, P. (2001). How do foreign patent rights affect U.S. exports, affiliate sales, and licenses? Journal of International Economics, 55, 411-439.

Smithers, J. and A. Blay-Palmer (2001). Technology Innovation as a Strategy for Climate Adaptation in Agriculture. Applied Geography, 21, 175-197.

Snyder L. D., N. H. Miller and R. N. Stavins (2003). The Effects of Environmental Regulation on Technology Diffusion: The Case of Chlorine Manufacturing. American Economic Review, 93(2), 431-435.

Stavins, R. N. (2008). Environmental Economics. In Durlauf S.N. and L. E. Blume (eds.) The New Palgrave Dictionary of Economics, Second Edition.

Stern, N. (2006). The Economics of Climate Change. HM Treasury, London.

Taylor, M. (2008). Beyond technology-push and demand-pull: Lessons from California's solar policy. Energy Economics, 30, 2829-2854.

Tol, R. S. (2008). Climate, Development, and Malaria: An Application of FUND. Climatic Change, 88, 21-34.

Tol, R. S. (2009). The Economic Effects of Climate Change. Journal of Economic Perspectives 23(2), 29-51.

Turner, J. L., and P. Heald (2004). Intellectual Property and Foreign Direct Investment: Improving upon Mansfield's 1991 Survey, Preliminary Report. Atlanta, GA: University of Georgia. Available at http://media.terry.uga.edu/myila/pdf/RRTurner.pdf 
UNFCCC (2010). Report of the Ad Hoc Working Group on Long-term Cooperative Action under the Convention on its eighth session, held in Copenhagen from 7 to 15 December 2009. FCCC/AWGLCA/2009/17.

WHO (2009). Protecting Health from Climate Change: Global Research Priorities. Geneva.

Wing, I.S. (2007). Explaining the declining energy intensity of the U.S. economy. Resource and Energy Economics, 30, 21-49.

Winters, P., R. Murgai, E. Sadoulet, A. de Janvry, and G. Frisvold (1998). Economic and Welfare Impacts of Climate Change on Developing Countries. Environmental and Resource Economics, 12, 1-24.

World Bank (2010). World Development Report 2010: Development and Climate Change. Washington D.C.

Wright, B., and T. Shih (2010). Agricultural Innovation. NBER Working Paper No. 15793.

Wright, B., and P. G. Pardey (2006). Changing intellectual property regimes: implications for developing country agriculture. International Journal of Technology and Globalisation, 2(1/2), 93-114.

Yang, L. and K. E. Maskus (2009). Intellectual property rights, technology transfer and exports in developing countries. Journal of Development Economics, 90, 231-236.

Yohe, G. and M. Schlesinger (2002). The Economic Geography of the Impacts of Climate Change. Journal of Economic Geography, 2, 311-341.

Youngman, R., J. Schmidt, J. Lee, and H. de Coninck (2007). Evaluating technology transfer in the Clean Development Mechanism and Joint Implementation. Climate Policy, 7, 488-499.

Zhao, M. (2006). Conducting R\&D in Countries with Weak Intellectual Property Rights Protection. Management Science, 52 (8), 1185-1199. 